\title{
Direct-DME SOFC for Intermediate Operation Temperature Using Proton Conductor as the Electrolyte
}

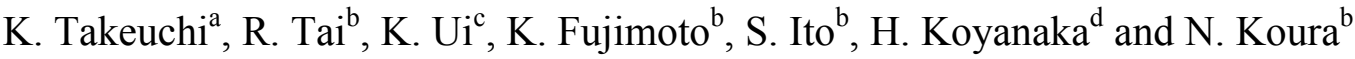 \\ ${ }^{a}$ Faculty of Industrial Science and Technology, Tokyo University of Science, 102-1 \\ Tomino, Oshamanbe, Hokkaido 049-3514, Japan \\ ${ }^{b}$ Faculty of Science and Technology, Tokyo University of Science, 2641 Yamazaki, Noda, \\ Chiba 278-8510, Japan \\ ${ }^{c}$ Department of Frontier Materials and Functional Engineering, Graduate School of \\ Engineering, Iwate University, Morioka, Iwate 020-8551, Japan \\ ${ }^{\mathrm{d}}$ Institute for Integrated Cell-Material Sciences, Kyoto University, Kyoto, 606-8501, \\ Japan
}

We have developed intermediate-temperature solid oxide fuel cell (SOFC) with a proton conducting oxide $\mathrm{BaCe}_{0.8} \mathrm{Y}_{0.2} \mathrm{O}_{3-\delta}$ (BCY20) as the electrolyte for direct utilization of dimethylether (DME) fuel. We tried to improve the cell performance of the SOFC by using Fe, $\mathrm{Fe}-\mathrm{Ni}$ and $\mathrm{Fe}-\mathrm{Pd} / \mathrm{MnO}_{2}$ as a catalyst for the anode. Fe showed high catalytic activity for DME, furthermore attending $\mathrm{Ni}$ or $\mathrm{Pd} / \mathrm{MnO}_{2}$ catalysts to Fe remarkably improved the cell performance.

\section{Introduction}

Solid Oxide Fuel Cell (SOFC) has higher power generation efficiency and more fuel flexibility than other fuel cells and is developed for practical use (1). However, existing SOFC were operated at about $1000^{\circ} \mathrm{C}$. High operating temperatures precludes the use of inexpensive metal components as interconnects. It also produces thermal stresses and solid-phase reactions (2) (3). Furthermore, using hydrogen as fuel is impractical in terms of storage and handling (4) (5). Recently, many researchers make an effort to operate SOFC at intermediate-temperatures $\left(600^{\circ} \mathrm{C}-800^{\circ} \mathrm{C}\right)$ and to accomplish direct utilization of hydrocarbon fuel at the same time (6)-(9). In order to enable fuel cells to operate at intermediate-temperatures, it is necessary to develop the electrolyte that has high ionic conductivity at these temperatures. Iwahara, et al. reported that $\mathrm{BaCe}_{0.8} \mathrm{Y}_{0.2} \mathrm{O}_{3-\delta}(\mathrm{BCY} 20)$ showed about $0.03 \mathrm{Scm}^{-1}$ ionic conductivity (10) at $600^{\circ} \mathrm{C}$ and transference number of proton was almost one (11). On the other hand, Dimethylether (DME) is one of the candidates for fuel of the intermediate SOFC. First, DME gas becomes easily liquid with high pressure, second it is easily oxidized at intermediate-temperatures (12) and finally it is possible for DME to use the existing infrastructure for propane gas (13) (14). Besides, because of high cetane number and environmentally-friendly, DME is regarded as promising resource for future low emission society (15). In th is study, w e developed the direct-D M E fuel cell operated at in term ed iate-tem perature using B C Y 20 as a solid electrolyte (thickness $500 \mu \mathrm{m}$ ). Especially, w e focused developm ent of anodic catalysts. The Fe, Fe-Ni and $\mathrm{Fe}-\mathrm{Pd} / \mathrm{MnO}_{2}$ anode were developed.

\section{Experimental}

$\mathrm{BaCe}_{0.8} \mathrm{Y}_{0.2} \mathrm{O}_{3-\delta}(\mathrm{BCY} 20)$ powder was pressed in a pellet $(\Phi=20 \mathrm{~mm})$. This pellet was sintered at $1600^{\circ} \mathrm{C}$ for $12 \mathrm{~h}$ in air. The sintered pellet was polished to $0.5 \mathrm{~mm}$ in thick, and was used as the solid electrolyte. As a cathode, Pt paste (TR-7905, Tanaka precious 
metals) was applied to one side of the pellet $(\Phi=8 \mathrm{~mm})$, and calcined at $930^{\circ} \mathrm{C}$ for $1 \mathrm{~h}$ in air. Three kinds of anode materials $\mathrm{Fe}, \mathrm{Ni}-\mathrm{BCY} 20$, and $\mathrm{Fe}-\mathrm{Ni}$ were respectively used. $\mathrm{Fe}_{2} \mathrm{O}_{3}$ paste was prepared by mixing $\mathrm{Fe}_{2} \mathrm{O}_{3}$ powder (Aldrich) with a binder (TMS-1, Tanaka precious metals). NiO-BCY20 paste was prepared from TMS-1, NiO powder (Aldrich), and BCY20 powder. $\mathrm{Fe}_{2} \mathrm{O}_{3}-\mathrm{NiO}$ paste was prepared from TMS-1, $\mathrm{Fe}_{2} \mathrm{O}_{3}$ powder (Aldrich), and $\mathrm{NiO}$ powder (Aldrich). These anodic pastes were applied to the other side of the BCY20 pellet $(\Phi=8 \mathrm{~mm})$, and calcined at $800^{\circ} \mathrm{C}$ for $1 \mathrm{~h}\left(\mathrm{Fe}_{2} \mathrm{O}_{3}\right)$, at $1300^{\circ} \mathrm{C}$ for $1.5 \mathrm{~h}(\mathrm{NiO}-\mathrm{BCY} 20)$, and at $900^{\circ} \mathrm{C}$ for $2 \mathrm{~h}\left(\mathrm{Fe}_{2} \mathrm{O}_{3}-\mathrm{NiO}\right)$ in air. Before the electrochemical measurements, these oxides were reduced to $\mathrm{Fe}, \mathrm{Ni}-\mathrm{BCY} 20$, and Fe-Ni in $\mathrm{H}_{2}$ gas at $600^{\circ} \mathrm{C}$. $\mathrm{V}-\mathrm{I}$ characteristics were measured by using a galvanostat (NPGFZ251-B, Nikko Keisoku) at $600^{\circ} \mathrm{C}$.

\section{Results and discussion}

Fe, Pt and $\mathrm{Ni}-\mathrm{BaCe}_{0.8} \mathrm{Y}_{0.2} \mathrm{O}_{3-\delta}$ catalysts were used as the anodic materials of an intermediate temperature SOFC for direct utilization of DME gas fuel. The cell was operated at $600^{\circ} \mathrm{C}$. The maximum power density of the cell with the $\mathrm{Fe}$ anodic catalyst was $36.4 \mathrm{mWcm}^{-2}$ at $70 \mathrm{mAcm}^{-2}$, while the maximum power density of the cell with a Ni-BCY20 and the Pt anode were $5.5 \mathrm{mWcm}^{-2}$ at $10 \mathrm{mAcm}^{-2}$ and $8.4 \mathrm{mWcm}^{-2}$ at 20 $\mathrm{mAcm}^{-2}$, respectively (Fig. 1).

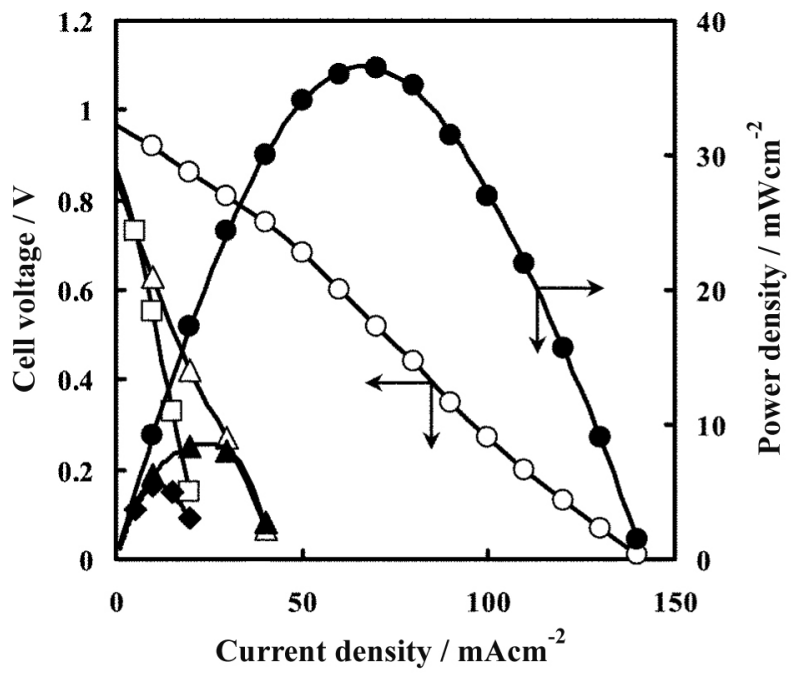

Fig. 1 Cell performance test with DME gas fuel at $600^{\circ} \mathrm{C}$.

Anode; $\bigcirc \mathbf{O}: \mathrm{Fe}, \triangle \boldsymbol{\Lambda}: \mathrm{Pt}, \square \mathbf{\square}: \mathrm{Ni}-\mathrm{BCY} 20$

We considered anodic reactions of DME fuel with gas chromatograph (Fig. 2). This result suggested $\mathrm{Fe}$ catalyst decomposes $\mathrm{DME}$ to $\mathrm{H}_{2}, \mathrm{CO}$ and $\mathrm{CH}_{4}$ at $600^{\circ} \mathrm{C}$. And it was found that $\mathrm{H}_{2}$ and $\mathrm{CO}$ could be used as the fuels in this SOFC, however most of $\mathrm{CH}_{4}$ was not used. So, it is necessary to accelerate utilization of $\mathrm{CH}_{4}$ as fuel and to improve the cell performance and utilization efficiency of DME fuel. 


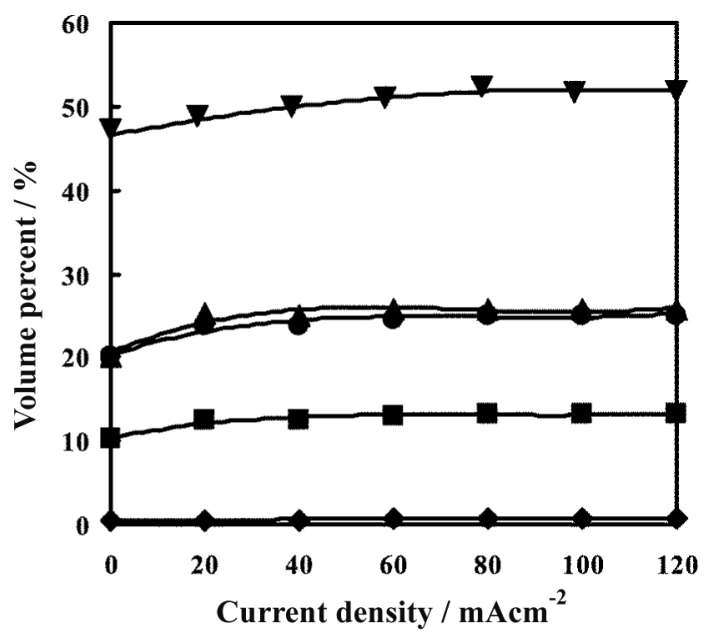

Fig. 2 Composition of outlet gas from the cell using Fe anode with DME gas fuel at $600^{\circ} \mathrm{C}$.

$\boldsymbol{\nabla}$ : DME conversion, Formation rate $: \mathrm{H}_{2}, \boldsymbol{\Delta}: \mathrm{CH}_{4}, \mathbf{\square}: \mathrm{CO}, \diamond: \mathrm{CO}_{2}$.

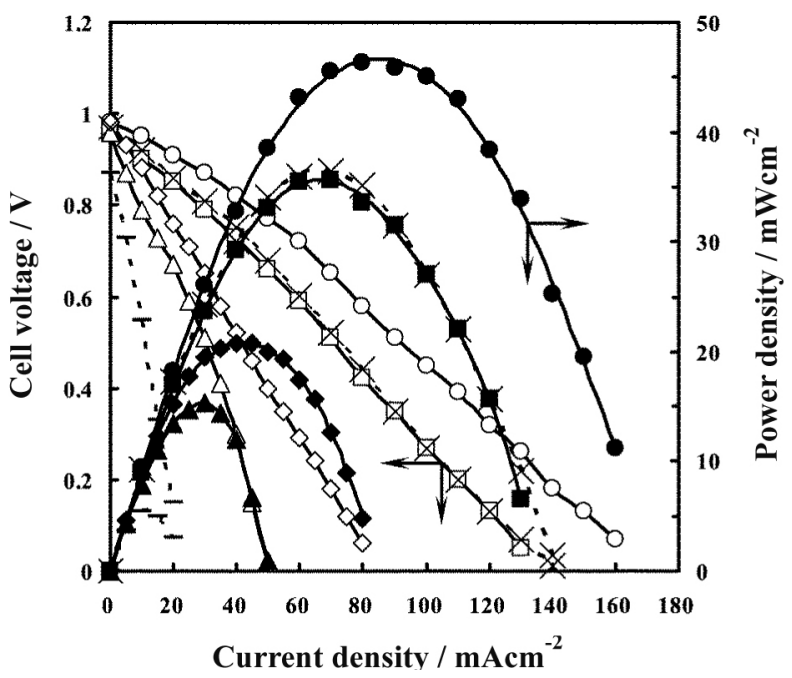

Fig. 3 Cell performance test with DME gas fuel at $600^{\circ} \mathrm{C}$.

Anode; $\times$ : Fe $\bigcirc$, O: Fe9-Ni1 $\square$, $\mathbf{a}$ : Fe8-Ni2

$\diamond, \diamond:$ Fe7-Ni3 $\triangle, \boldsymbol{\Delta}:$ Fe5-Ni5 - : Ni-BCY20.

Perry Murray et al. (16) reported a high catalytic activity of $\mathrm{Ni}$, which is also inexpensive material as well as $\mathrm{Fe}$, for $\mathrm{CH}_{4}$ decomposition in a direct-methane fuel cell. So, the addition of $\mathrm{Ni}$ to $\mathrm{Fe}$ anode was investigated. Figure 3 shows the $V-I$ characteristics measured using various Fe-Ni anodes with supplying DME gas directly to the anode side. By using the Fe9-Ni1 anode, OCV of the cell was $0.98 \mathrm{~V}$ and the maximum power density of the cell was $46.4 \mathrm{mWcm}^{-2}$ at $80 \mathrm{mWcm}^{-2}$. The maximum power density was improved about $27 \%$ compare with the Fe anode. The Fe9-Nil anode showed remarkable improvement of cell performance compared with the Fe anode. The reason $\mathrm{Fe}-\mathrm{Ni}$ anode showed superior performance is assumed that $\mathrm{Ni}$ in the anode promoted steam reforming of $\mathrm{CH}_{4}$ produced from DME and amount of $\mathrm{H}_{2}$ and $\mathrm{CO}$ which can use as fuel were increased. 
On the other hand, we had found that the $\mathrm{Pd} / \mathrm{MnO}_{2}$ catalyst decomposed $\mathrm{CH}_{4}$ at an intermediate-temperature. The $\mathrm{Pd} / \mathrm{MnO}_{2}$ catalyst had morphology that nano-Pd particles were dispersed on a manganese oxide with meso-scaled pores. Therefore, we attempted $\mathrm{Pd} / \mathrm{MnO}_{2}$ catalyst to anode material for intermediate-temperature SOFC. The cell was operated at $600{ }^{\circ} \mathrm{C}$. Maximum power density of the cell using $\mathrm{Pt}-\mathrm{Pd} / \mathrm{MnO}_{2}$ anode $\left(\mathrm{Pd} / \mathrm{MnO}_{2}\right.$ content of 16.6 wt.\%) was $21 \mathrm{mWcm}^{-2}$ at $50 \mathrm{mWcm}^{-2}$, while the cells using Pt and $\mathrm{Pd} / \mathrm{MnO}_{2}$ as anode materials exhibited maximum power densities of 9 and $10 \mathrm{mWcm}$ -2 at $20 \mathrm{mWcm}^{-2}$, respectively (Fig. 4).

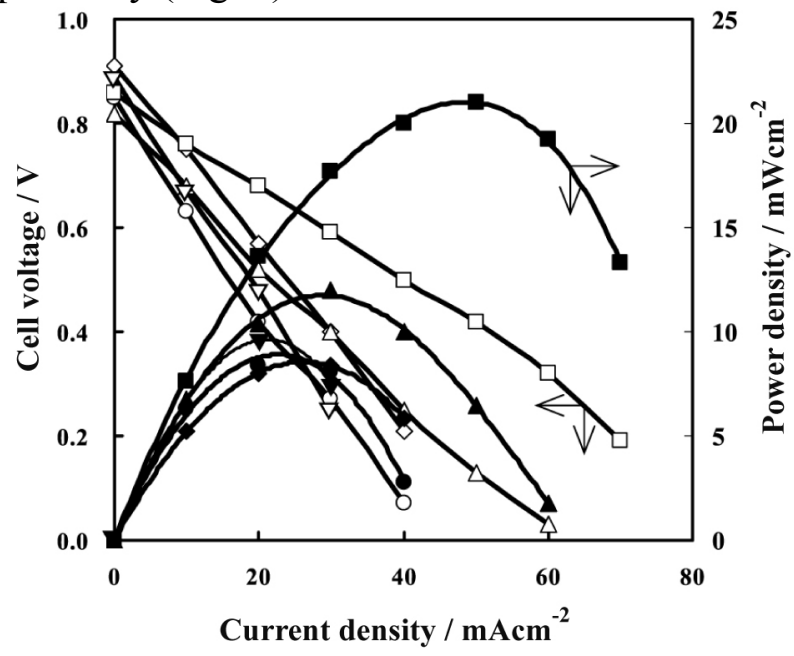

Fig.4 Cell performance test with DME gas fuel at $600^{\circ} \mathrm{C}$.

Anode; $\bigcirc, \mathbf{P}: \mathrm{Pt}, \square$, $\mathbf{\square}: \mathrm{Pt}-\mathrm{Pd} / \mathrm{MnO}_{2}\left(\mathrm{Pd} / \mathrm{MnO}_{2} 16.6\right.$ wt.\% in anode), $\triangle, \boldsymbol{\Delta}: \mathrm{Pt}-\mathrm{MnO}_{2}$ $\left(\mathrm{MnO}_{2} 25.0\right.$ wt.\% in anode), $\diamond, \diamond: \mathrm{Pt}-\mathrm{Pd}\left(\mathrm{PdO} 4.1\right.$ wt.\% in anode), $\nabla, \boldsymbol{\nabla}: \mathrm{Pd} / \mathrm{MnO}_{2}$.

It was found that $\mathrm{Pd} / \mathrm{MnO}_{2}$ showed higher activity for anode catalyst of SOFC. So, the addition of $\mathrm{Pd} / \mathrm{MnO}_{2}$ to $\mathrm{Fe}$ anode was also investigated. As the result, the $\mathrm{Fe}-\mathrm{Pd} / \mathrm{MnO} \mathrm{O}_{2}$ (7-3 weight ratio) anode showed $58.8 \mathrm{mWcm}^{-2}$ maximum power density with $\mathrm{DME}$ at $600^{\circ} \mathrm{C}$. The maximum power density was improved about $62 \%$ compare with the $\mathrm{Fe}$ anode (Fig. 5).

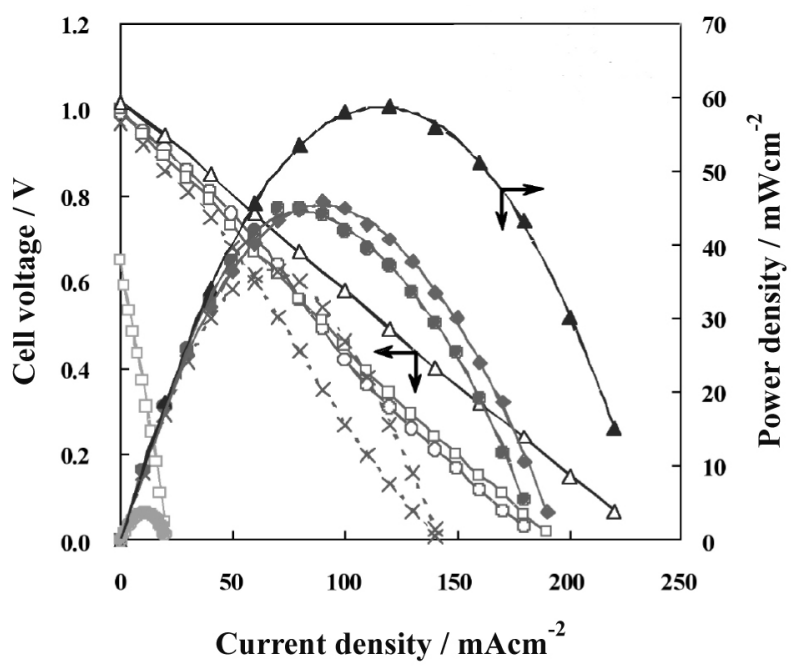

Fig. 5 Cell performance test with DME gas fuel at $600^{\circ} \mathrm{C}$.

Anode; $\bigcirc$ : Fe:Ni=9:1(molar ratio), $\triangle \mathbf{\Delta}: 7: 3, \diamond \bullet: 5: 5, \square \mathbf{\square}: \mathrm{Pd} / \mathrm{MnO}_{2}, \mathrm{X}: \mathrm{Fe}$ 
It was concluded that $\mathrm{Fe}$ showed high catalytic activity for DME, furthermore attending $\mathrm{Ni}$ or $\mathrm{Pd} / \mathrm{MnO}_{2}$ catalysts to Fe remarkably improved the cell performance.

\section{References}

1. J. P. P. Huijsmans, F. P. F. van Berkel, G. M, Christie, J. Power Sources, 71, 107 (1998).

2. T. Ishihara, M. Honda, T. Shibayama, H. Minami, H. Nishiguchi, Y. Takita, J. Electrochem. Soc., 145, 3177 (1998).

3. C. Lu, W. L. Worrell, R. J. Gorte, J. M. Vohs, J. Electrochem. Soc., 150, A354 (2003).

4. T. Hibino, A. Hashimoto, T. Inoue, J. Tokuno, S. Yoshida, M. Sano, Science, 288, 2031 (2004).

5. G. A. Deluga, J. R. Salge, L. D. Schmidt, X. E. Verykios, Science, 303, 993 (2004).

6. E. P. Murray, T. Tsai, S. A. Barnett, Nature, 400, 649 (1999).

7. S. Park, R.J. Gorte, J.M. Vohs, J. Electrochem. Soc., 148, A443 (2001).

8. Y. Jiang, A.V. Virkar, J. Electrochem. Soc., 148, A706 (2001).

9. C. Lu, S. An, W.L. Worrell, J.M. Vohs, R.J. Gorte, Solid State Ionics, 175, 47 (2004).

10. H. Iwahara, Solid State Ionics, 77, 289 (1995).

11. J. Guan, S. E. Dorris, U. Balachandran, M. Liu, J. Electrochem. Soc., 145, 1780 (1998).

12. S. Wang, T. Ishihara, Y. Takita, Appl. Catal., A, 228, 167 (2002).

13. E.P. Murray, S.J. Harris, H. Jen, J. Electrochem. Soc., 149, A1127 (2002).

14. W. Shi-zhong, G. Jie, Electrochem. Solid-State Lett., 9, A395 (2006).

15. C. M. R. Reyes, J. S. Francisco, J. J. Szente, M. M. Maricq, L. F. Ostergaard, J. Phys. Chem. A, 109, 10940 (2005).

16. E.Perry Murray, T. Tsai, S. A. Barnett, Nature Lett., 649 (1999). 